Вісник Львівського торговельно-економічного університету. Економічні науки. 2019. Вип. 57.

\title{
УДК 338.24:334.012.64
}

Барна М. Ю.,

ORCID ID: 0000-0001-5248-9774, Researcher ID: G-9493-2019, д.е.н., дои., перший проректор, професор кафедри туризму та готельно-ресторанної справи, Львівський торговельноекономічний університет, м. Львів

Мороз С. Г.,

завідувач Полтавського відділення Харківського науково-дослідного інституту судових експертиз імені М. С. Бокаріуса, м. Полтава

\section{КОНЦЕПТУАЛЬНІ ЗАСАДИ ФОРМУВАННЯ ІНСТРУМЕНТІВ РЕГУЛЯТОРНОЇ ПОЛІТИКИ РОЗВИТКУ МАЛОГО ПІДПРИЕМНИЦТВА}

\begin{abstract}
Анотація. Мета статті полягає у здійсненні аналізу інструментів реалізації регуляторноі політики сектора малого підприємництва. У роботі досліджено нормативно-правове забезпечення державної регуляторної політики в цілях ідентифікаиії інструментів ії реалізачії. Проведено аналіз економічної літератури стосовно існуючих класифікаиій інструментів державної регуляторної політики. Подано характеристику та графічно зображено послідовність організаиійної прочедури реалізаиї регуляторної політики, де кожен з етапів та заходів такого алгоритму фактично й слугує відповідним інструментом. Описано макроекономічний, фінансово-ресурсний, технікотехнологічний, інтелектуально-кадровий, інвестиційно-інноваційний, інформаційно-комунікаційний, функиіональні інструменти реалізації регуляторної політики сектора малого підприємництва. Доведено, що центральним елементом державної регуляторної політики розвитку малого підприємництва є формування якісного нормативно-правового поля комериійної господарської діяльності, а допоміжними - економічна, організаційна, інфраструктурна та ресурсна складові. Реалізаиія державної регуляторної політики потребує формування і реалізащії системної сукупності інструментів за групами: нормативно-процедурні, функціональні, структурні, управлінські, інституційно-організаційні, спеціалізовані.
\end{abstract}

Ключові слова: інструменти, регуляторна політика, державне регулювання, мале підприємництво, соціально-економічний розвиток.

Barna M. Y., ORCID ID: 0000-0001-5248-9774,Researcher ID: G-9493-2019,

Doctor of Economics, Associate Professor, First Vice-Rector, Professor of the Department of Tourism and Hotel\&Restaurant Business, Lviv University of Trade and Economics, Lviv

Moroz S. G.,

Head of the Poltava branch of the Kharkiv Research Institute of Forensic Expertise named after M. S. Bokarius, Poltava

\section{CONCEPTUAL PRINCIPLES OF FORMING INSTRUMENTS FOR REGULATORY POLICY OF SMALL ENTREPRENEURHIP DEVELOPMENT}

\footnotetext{
Abstract. The purpose of the article is to analyze the instruments for implementing the regulatory policy of the small entrepreneurship sector. The article examines the legal and regulatory framework for state regulatory policy in order to identify the instruments for its implementation. The analysis of economic literature concerning the existing classification of state regulatory policy instruments has been carried out. A characteristic and a graphic representation of the organizational procedure sequence for the regulatory policy implementation is presented, where each of the stages and measures of such an algorithm actually serves as
} 
Вісник Львівського торговельно-економічного університету. Економічні науки. 2019. Вип. 57.

an appropriate instrument. The macroeconomic, financial, resourcing, technical, technological, intellectual, personnel, investment, innovative, informational, communicatinal as well as functional instruments for the regulatory policy implementation of the small entrepreneurship sector are described. It is proved that the central element of the state regulatory policy of small entrepreneurhip development is the formation of a qualitative legal and regulatory framework for commercial economic activity, and the auxiliary ones are economic, organizational, infrastructure and resource components. Implementation of the state regulatory policy requires the formation and implementation of a systemic set of instruments related to the following groups: normative-procedural, functional, structural, managerial, institutional, organizational, specialized.

Key words: instruments, regulatory policy, state regulation, small entrepreneurhip, social and economic development.

JEL Classification: L51; M21; O29

DOI: https://doi.org/10.36477/2522-1205-2019-57-02

Постановка проблеми. Регуляторна політика у сфері малого підприємництва є невід'ємним елементом системи державного регулювання розвитку цього сектора національного господарства, відповідальним за підвищення рівня якості державного управління шляхом створення необхідного нормативно-правового середовища здійснення підприємницької діяльності, іiі адміністрування 3 боку органів влади і місцевого самоврядування, формування умов, необхідних для активізації малого бізнесу, реалізації його ролі в економіці, зміцнення конкурентоспроможності та покращення структурних характеристик сектора малого підприємництва. Оскільки основною метою регуляторної політики розвитку малого підприємництва $є$ забезпечення високого рівня якості державної політики у даній сфері, актуалізується потреба аналізу інструментарію реалізації регуляторної політики сектора малого підприємництва, який буде залучено для досягнення мети політики та ії ключових завдань.

Аналіз останніх досліджень і публікацій. Вивченню теоретичних засад регуляторної політики та розробленню класифікації інструментів іiі реалізації присвячені праці А. Горобінської [1], С. Степаненко [8], М. Погрібняка [5], О. Мордвінова [6]. Над дослідженням функціональних аспектів застосування інструментів реалізації регуляторної політики працювали вчені 3. Варналій, І. Кузнєцова [2], Г. Кампо [4], Д. Ляпін та К. Ляпіна [7]. Проте питання дослідження інструментів реалізації регуляторної політики сектора малого підприємництва залишається недостатньо розкритим.

Постановка завдання. Метою статті $є$ аналіз інструментів реалізації регуляторної політики сектора малого підприємництва.

Виклад основного матеріалу дослідження. Відомо, що інструменти державної політики слугують тими засобами, за допомогою яких держава встановлює вимоги до підприємств і громадян. Інструменти здебільшого прописуються в законах, формальних і неформальних розпорядженнях, допоміжних правилах, які встановлюються державою, а також недержавними організаціями, саморегулюючими структурами, яким держава делегувала регуляторні повноваження. Саме за допомогою інструментів і здійснюється державне регулювання соціально-економічних процесів та явищ.

Звернімо увагу на те, що в контексті регуляторної політики низка інструментів безпосередньо прописана у профільному законодавчому акті нашої держави. Мова йде про такі інструменти, як планування регуляторних актів, підготовка аналізу регуляторного впливу, оприлюднення проектів рішень органів влади та місцевого самоврядування, відстеження результативності регуляторних актів, їх перегляд та офіційне оприлюднення, висвітлення інформації про здійснення та результати регуляторної діяльності і т. ін. Разом із тим, зазначений перелік не зовсім вписується в класичне розуміння поняття “інструмент" як інститут державного регулювання економіки.

Адже в класиці державного регулювання економіки до інструментів державного регулювання, як правило, відносять такі більш конкретні способи державного впливу, як фіскальна та бюджетна політика, система оподаткування, ліцензування, запровадження різного роду економічних стимулів та мотивів, державно-приватне партнерство, розвиток інфраструктури і т. ін.

Відтак у цілях ідентифікації інструментів, характерних для державної регуляторної політики, доречно проаналізувати відповідну практику функціонування державної структури, відповідальної за політику в аналізованій сфері. В Україні це Державна регуляторна служба України, створена у 2014 р. згідно з Постановою Кабінету Міністрів України “Про деякі питання Державної регуляторної служби України” [3].

Цією ж постановою затверджене положення про Державну регуляторну службу України, 3 якого, щоправда, робимо висновок, що реалізація державної регуляторної політики (незважаючи на назву цієї структури) не є єдиним виключним завданням зазначеного урядового органу. На нього також покладені завдання реалізації політики 3 питань нагляду (контролю), а також ліцензування та дозвільної системи у сфері господарської діяльності, координації діяльності владних структур, громадянського суспільства та підприємницького сектора відносно дерегулювання господарської діяльності. Як можемо констатувати, друга частина завдань у 


\section{Вісник Львівського торговельно-економічного університету. Економічні науки. 2019. Вип. 57.}

достатній мірі виходить за рамки класично-правового підходу до трактування сутності і змісту регуляторної політики. Хоча, з іншого боку, дає підстави відносно передбачення таких завдань в рамках інструментів державної регуляторної політики, особливо у сфері забезпечення розвитку сектора малого підприємництва.

Так, виходячи 3 організаційно-управлінської структури Державної регуляторної служби України, можна виокремити такі інструменти, що мають місце в іiі діяльності при виконанні відповідних функціональних обов'язків: 1) експертиза та аналізування ефективності нормативно-правових актів; 2) координація діяльності та нормативно-правовий супровід елементів дозвільної системи; 3) здійснення договірної та претензійної роботи у сфері адміністративно-господарської діяльності; 4) координація діяльності органів влади, інститутів громадянського суспільства та підприємництва 3 питань коригування регуляторної політики та дерегуляції бізнесу; 5) використання зв'язків і можливостей міжнародного співробітництва у сфері регуляторної політики, 6) інформаційно-аналітичні заходи та супровід регуляторної діяльності.

Зауважимо, що інструментарій державної регуляторної політики, у т. ч. в царині забезпечення розвитку малого підприємництва, об'єктивно як доволі обмежений (передусім з огляду на те, що регуляторна політика й сама виступає інструментом державного регулювання), так і надто обширний (оскільки стосується аналізу й експертизи усіх без виключення нормативно-правових актів - від дріб'язкових рішень найменших (за адміністративно-територіальним підходом) органів влади до національних стратегій і програм).

Відтак, 3 огляду на ці обставини, абсолютно правомірним може бути висновок про доречність не стільки виокремлення конкретних інструментів регуляторної політики, як скоріше формування розлогої їх класифікації. Адже значна варіативність інструментів регуляторної політики підтверджується, наприклад, тим, що А. Горобінська сюди відносить збалансування інтересів суб'єктів суспільно-економічних відносин [1, с. 234]; С. Степаненко - здійснення послідовних регулюючих дій до моменту напрацювання та в подальшому прийняття найбільш якісного управлінського рішення [8, c. 149]; М. Погрібняк - впровадження набору процедурних та організаційних засобів регулювання в найбільш важливих і актуальних на сьогодні сферах i секторах економіки, видах економічної діяльності [5, с. 9]; О. Мордвінов - дотримання наперед визначених чітких алгоритмів і послідовностей, що стандартизують процеси державного управління економікою [6].

Ряд такого типу прикладів прописаних в економічній літературі інструментів державної регуляторної політики можна й надалі продовжувати, а за умови доєднання сюди ще й інструментів у сфері підтримки розвитку малого підприємництва варіативність інструментарію регуляторної політики ще на порядок зростає.
Відтак, на нашу думку, певні обмеження щодо кількісно-якісного складу інструментів державної регуляторної політики лише звужуватимуть можливості державного регулювання, тому доречніше вести мову про склад інструментів, сформованих у відповідності до певної логіки (класифікації).

Беззаперечно, що використовувані класифікаційні ознаки та їх послідовність також відіграють неабияку роль. Зокрема, в першу чергу потрібно врахувати нормативно-процедурний або ж інституційно-технологічний аспект. Тобто в процесі провадження регуляторної політики іï суб'єкти (органи влади та місцевого самоврядування, спеціалізований державний орган в цій сфері та ін.) зобов'язані дотримуватися визначеної і законодавчо врегульованої послідовності. Кожен 3 етапів та заходів такого алгоритму фактично й слугує відповідним інструментом. Так, базовими 3 них $є$ інструменти планування, аналізу, підготовки, оприлюднення, погодження, відстеження результативності регуляторних актів, що реалізуються, у послідовності та відповідності до алгоритму, наведеного на рис. 1.

Як вже зазначалося вище, попри реалізацію безпосередніх інституційно-технологічних завдань регуляторна політика важлива й у контексті планування і забезпечення соціально-економічного розвитку територій, галузей економіки та видів економічної діяльності.

Відтак в їі арсеналі повинні бути передбаченими й функціональні інструменти.

У відповідності до теоретико-методичних напрацювань у цій сфері [2; 7; 4] до таких інструментів, як правило, відносять макроекономічний (орієнтований на створення сприятливого економіко-правового середовища бізнесу), фінансово-ресурсний (передбачає формування необхідного фінансового і ресурсного забезпечення функціонування та розвитку суб'єктів підприємницького сектора), техніко-технологічний (стосується підвищення рівня доступності сучасних техніки та технологій для організації виробничої, торговельної та іншої діяльності), інтелектуально-кадровий (пов'язаний з підготовкою кадрового ресурсу для бізнесу та його інтелектуального капіталу), інвестиційно-інноваційний (орієнтований на розвиток середовища інвестиційної та інноваційної діяльності), інформаційно-комунікаційний (пов'язаний 3 розвитком цифрової економіки та впровадженням в бізнес інформаційно-комунікаційних технологій), ін.

Немаловажною є й роль регуляторної політики в контексті реалізації структурних реформ у національній економіці. До слова: розвиток, зміцнення конкурентоспроможності, реалізація потенціалу та ролі малого підприємництва у системі національного господарства завжди відносилися до ключових завдань структурної економічної політики. Зреалізувати ці та інші завдання значно легше із застосуванням відповідних інструментів в рамках регуляторної політики. Це, до прикладу, грантове бюджетування, субсидування, зовнішньоторговельний протекціонізм, фінансово-кредитна підтримка i допомога, розподіл та перерозподіл фінансових 
Вісник Львівського торговельно-економічного університету. Економічні науки. 2019. Вип. 57.

ресурсів, напрямів фінансування відповідних секторів національної економіки, організація приватнопублічного інвестування, сприяння в залученні інноваційно-технологічного забезпечення, різного роду інституціоналізаційні засоби.

Застосування інструментів регуляторної політики в таких цілях скеровується на зміну, удосконалення чи покращення ключових структурних характеристик в економіці для зміцнення ii конкурентоспроможності. Як правило, увага передусім приділяється: зростанню підприємницького сектора, нарощуванню інновацій та продуктивних інвестицій, розвитку базових видів економічної діяльності, нарощуванню виробничих потужностей 3 продукування продукції із значним вмістом доданої вартості і т. ін.

Державні органи влади та місцевого самоврядування

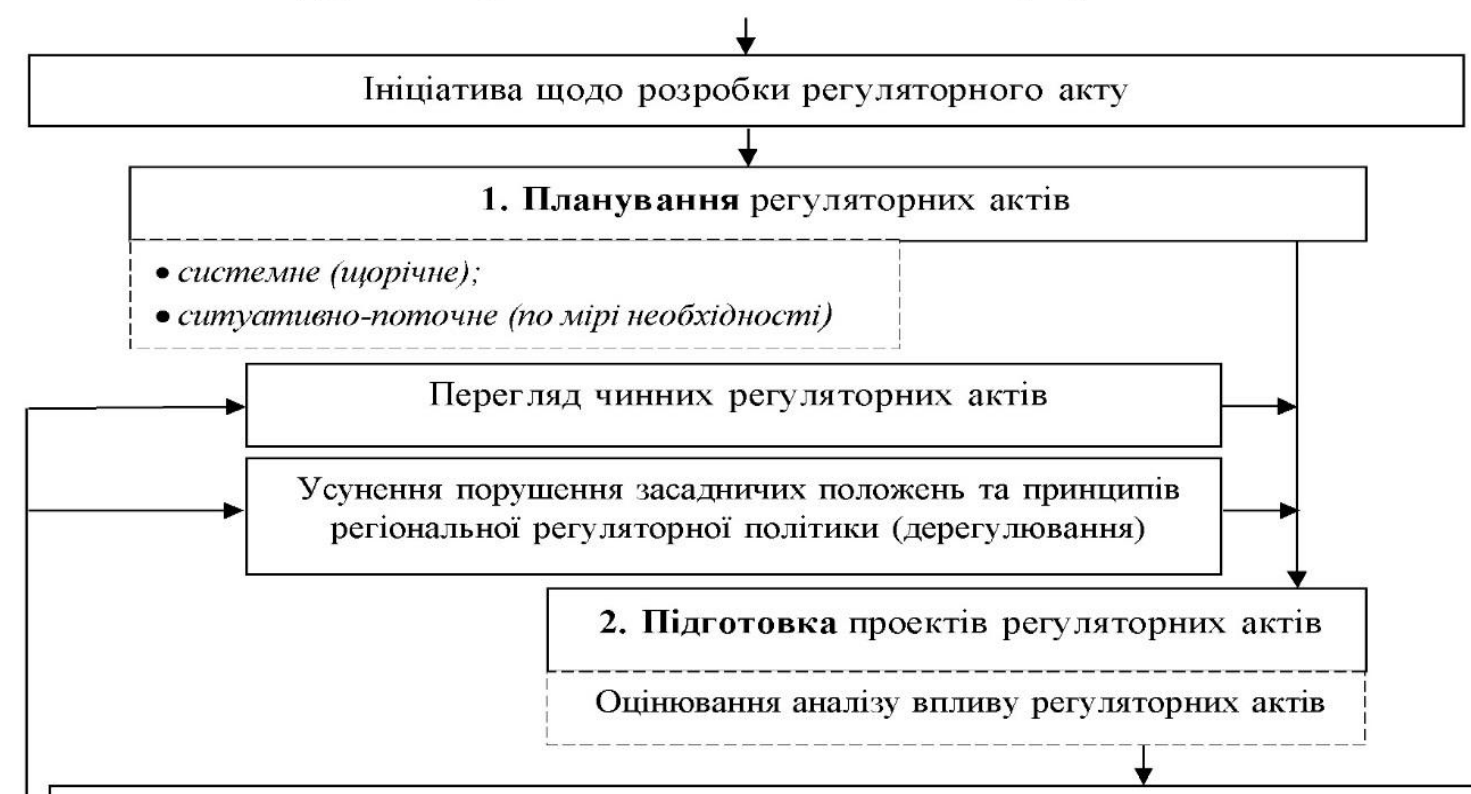

3. Оприлюднення просктів регуляторних актів та відстеження їх результативності

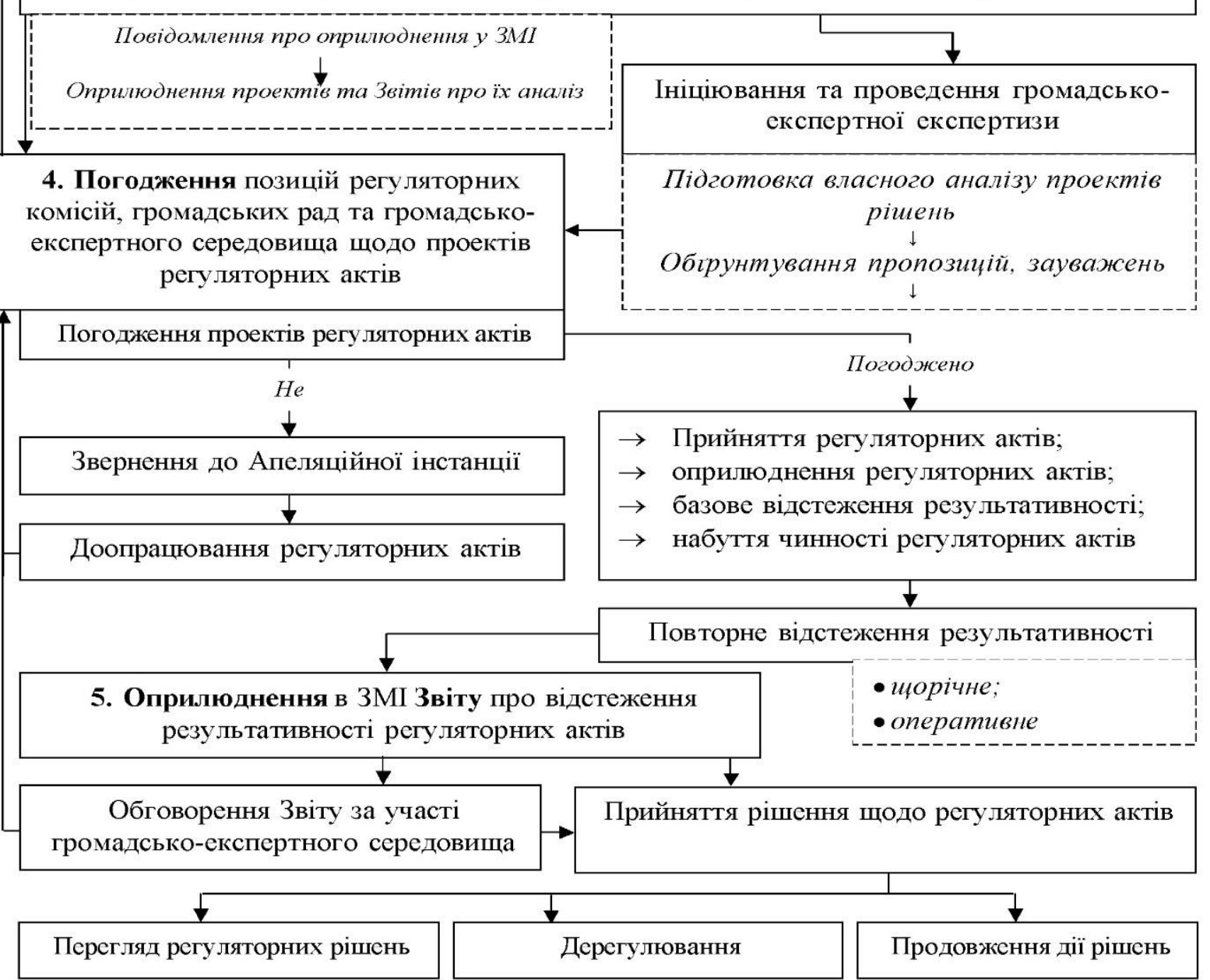

Рис. 1. Послідовність організаційної процедури реалізації регуляторної політики (узагальнено автором) 


\section{Вісник Львівського торговельно-економічного університету. Економічні науки. 2019. Вип. 57.}

Не відкидаємо також доцільності врахування безпосередніх управлінських інструментів, місце яких в структурі регуляторної політики держави об'єктивно природне. Адже прогалини в цій частині діяльності можуть стати критичними прорахунками в процесі державного управління розвитком як важливих макроекономічних складових, так i поступу сектора малого підприємництва.

Йдеться про інструменти - функції державної політики як-от - аналіз, діагностика та моніторинг, планування, організація, мотивація, контроль та ін.

В будь-якому разі, навіть за прийняття найбільш правильних i виважених управлінських рішень, державна політика може втратити свою ефективність за умови, якщо не буде сформовано якісної системи інституційного та організаційного базису управління. Йдеться про аспекти державної i недержавної організаційно-управлінської системи, що скеровуватиме всі процеси у правильному руслі, ініціюватиме заходи державного регулювання та здійснюватиме контроль за розвитком ситуації, а також інституційно-інфраструктурного забезпечення, без якого навіть найбільш успішні реформи не можуть мати стратегічних довгострокових наслідків.

Висновки і перспективи подалыших досліджень у даному напрямі. Отже, для забезпечення соціально-економічного розвитку територій, галузей економіки та видів економічної діяльності необхідним стає впровадження і використання таких інструментів, як організаційно-управлінський, реалізації стратегічних національних (та місцевих) проектів, інфраструктурний, міжгалузевої співпраці, міжсуб'єктного партнерства, локальної інтеграції. Імплементація цих інструментів дозволяє сформувати повноцінне середовище становлення i розвитку малого бізнесу, а також потенціалу реалізації регуляторної політики держави.

Додамо і те, що державне регулювання розвитку малого підприємництва є окремим самостійним напрямом державного управління економікою. Відтак у системі інструментів державної регуляторної політики в цій сфері слід відвести належне місце секторально-спеціалізованим інструментам. Це в першу чергу інструменти стратегування i програмування розвитку цього сектора економіки, фінансово-ресурсної підтримки активізації підприємницької діяльності, покращення інфраструктурного середовища малого підприємництва, формування якісного соціально-психологічного клімату для приватного бізнесу, а також фінансово-економічної безпеки підприємництва.

На наше переконання, саме комплексний i системний підхід до бачення та імплементації інструментів державної регуляторної політики в сфері розвитку малого підприємництва $є$ найбільш доречним. В іншому випадку регуляторна політика у цій сфері може набути ознак непропорційності та незбалансованості.

Підсумовуючи теоретико-методичні засади складу інструментів регуляторної політики, потрібно вказати на те, що якість і ефективність державної політики в тій чи іншій сфері в значній мірі залежить від чіткого та повноцінного розуміння об'єкта і предмета регулювання.

\section{ЛІТЕРАТУРА}

1. Горобінська І. В. Механізм реалізації державної регуляторної політики в сфері транспортної діяльності / I. В. Горобінська // Вісник Національного транспортного університету. - 2011. - № 24 (1). - C. 232-236.

2. Васильців Т. Г. Формування середовища економічної безпеки підприємництва в Україні / Васильців Т. Г. // Економічний часопис-XXI : Науковий журнал. - К. : Ін-т суспільної трансформації. - 2015. - № 3-4 (1). - С. 24-27.

3. Деякі питання державної регуляторної служби України. Постанова Кабінету Міністрів України № 724 від 24.12.2014 p. [Електронний pecypc]. - Режим доступу: http://www.drs.gov.ua/polozhennya-pro-sluzhbu/.

4. Кампо Г. М. Методичний підхід до вимірювання розвитку малого бізнесу в містах і районах регіону / Кампо Г. М. // Актуальні проблеми економіки. - 2008. - № 6 (84). - С. 169-179.

5. Мордвінов О. Г. Досвід формування механізму регуляторної політики в США та можливості застосування його в Україні / О. Г. Мордвінов, М. А. Погрібняк [Електронний ресурс]. - Режим доступу: http: //www.nbuv.gov.ua/PORTAL/Soc_Gum/Ptdu/2011_2/files/PD211_28.pdf.

6. Погрібняк М. А. Механізм державної регуляторної політики у сфері господарської діяльності : автореф. дис. ... канд. наук $з$ держ. упр. : 25.00.02 / Погрібняк М. А.; Класич. приват. ун-т. - Запоріжжя, 2008. -20 c.

7. Регуляторна політика як інструмент боротьби 3 корупцією. Конспект лекцій / [за ред. Д. В. Ляпіна та К. М. Ляпіної]. - К. : Ін-т Конкурентного Суспільства, 2007. - 228 с.

8. Степаненко С. В. Визначення основних засад регуляторного втручання в економіку залежно від функцій держави в реалізації цілей суспільного розвитку / С. В. Степаненко // Актуальні проблеми державного управління. - 2013. - № 1 (43). - С. 147 152.

\section{REFERENCES}

1. Horobins'ka, I. V. (2011), Mekhanizm realizatsii derzhavnoi rehuliatornoi polityky $\mathrm{v}$ sferi transportnoi diial'nosti, Visnyk Natsional'noho transportnoho universytetu, № 24 (1), s. 232-236.

2. Vasyl'tsiv, T. H. (2015), Formuvannia seredovyscha ekonomichnoi bezpeky pidpryiemnytstva $\mathrm{v}$ Ukraini, Ekonomichnyj chasopys-XXI : Naukovyj zhurnal., In-t suspil'noi transformatsii, K., № 3-4 (1), s. 2427.

3. Deiaki pytannia derzhavnoi rehuliatornoi sluzhby Ukrainy. Postanova Kabinetu Ministriv Ukrainy № 724 vid 24.12.2014 r., available at : http://www.drs.gov.ua/polozhennya-pro-sluzhbu/. 
Вісник Львівського торговельно-економічного університету. Економічні науки. 2019. Вип. 57.

4. Kampo, H. M. (2008), Metodychnyj pidkhid do vymiriuvannia rozvytku maloho biznesu $\mathrm{v}$ mistakh $\mathrm{i}$ rajonakh rehionu, Aktual'ni problemy ekonomiky, № 6 (84), s. 169-179.

5. Mordvinov, O. H. and Pohribniak, M. A. Dosvid formuvannia mekhanizmu rehuliatornoi polityky $\mathrm{v}$ SShA ta mozhlyvosti zastosuvannia joho v Ukraini, available at : http: //www.nbuv.gov.ua/PORTAL/Soc_Gum/Ptdu/2011_2/files/PD211_28.pdf.

6. Pohribniak, M. A. (2008), Mekhanizm derzhavnoi rehuliatornoi polityky u sferi hospodars'koi diial'nosti : avtoref. dys. ... kand. nauk z derzh. upr. : 25.00 .02 ; Klasych. pryvat. un-t, Zaporizhzhia, $20 \mathrm{~s}$.

7. Rehuliatorna polityka iak instrument borot'by $z$ koruptsiieiu. Konspekt lektsij, za red. D. V. Liapina ta
K. M. Liapinoi (2007), In-t Konkurentnoho Suspil'stva, K., $228 \mathrm{~s}$.

8. Stepanenko, S. V. (2013), Vyznachennia osnovnykh zasad rehuliatornoho vtruchannia $\mathrm{v}$ ekonomiku zalezhno vid funktsij derzhavy $\mathrm{v}$ realizatsii tsilej suspil'noho rozvytku, Aktual'ni problemy derzhavnoho upravlinnia, № 1 (43), s. 147-152.

Стаття надійшла до редакиії 13 лютого $2019 p$. 